\title{
Glycyl-alanyl-histidine protects PC12 cells against hydrogen peroxide toxicity
}

\author{
Hideki Shimura ${ }^{1,3^{*}}$, Ryota Tanaka ${ }^{2}$, Yoshiaki Shimada ${ }^{1}$, Kazuo Yamashiro ${ }^{2}$, Nobutaka Hattori ${ }^{2}$ and Takao Urabe ${ }^{1}$
}

\begin{abstract}
Background: Peptides with cytoprotective functions, including antioxidants and anti-infectives, could be useful therapeutics. Carnosine, $\beta$-alanine-histidine, is a dipeptide with anti-oxidant properties. Tripeptides of Ala-His-Lys, Pro-His-His, or Tyr-His-Tyr are also of interest in this respect.

Results: We synthesized several histidine-containing peptides including glycine or alanine, and tested their cytoprotective effects on hydrogen peroxide toxicity for PC12 cells. Of all these peptides (Gly-His-His, Ala-His-His, Ala-His-Ala, Ala-Ala-His, Ala-Gly-His, Gly-Ala-His (GAH), Ala-His-Gly, His-Ala-Gly, His-His-His, Gly-His-Ala, and Gly-Gly-His), GAH was found to have the strongest cytoprotective activity. GAH decreased lactate dehydrogenase $(\mathrm{LDH})$ leakage, apoptosis, morphological changes, and nuclear membrane permeability changes against hydrogen peroxide toxicity in PC12 cells. The cytoprotective activity of GAH was superior to that of carnosine against hydrogen peroxide toxicity in PC12 cells. GAH also protected PC12 cells against damage caused by actinomycin D and staurosporine. Additionally, it was found that GAH also protected SH-SY5Y and Jurkat cells from damage caused by hydrogen peroxide, as assessed by LDH leakage.
\end{abstract}

Conclusion: Thus, a novel tripeptide, GAH, has been identified as having broad cytoprotective effects against hydrogen peroxide-induced cell damage.

\section{Backgrounds}

More than 7000 peptides have been identified as playing crucial roles in human physiology, including those acting as hormones, neurotransmitters, growth factors, ion channel ligands, or having anti- microbial activity [1-4]. Peptides are selective and efficacious signaling molecules that bind to specific cell surface receptors where they induce intracellular effects. Peptides represent an excellent starting point for the design of novel therapeutics. Even small peptides, such as dipeptides and tripeptides, may also have potent functions [5-8]. Some have cytoprotective functions and have been used in clinical trials for human disease [9]. Carnosine is a well-characterized antioxidant dipeptide composed of $\beta$-alanine and histidine. It has cytoprotective activity against various stresses as determined in both in vitro and in vivo models [10]. The imidazole ring of histidine is reported to have an important role in antioxidant cell protection [11]. Carnosine

\footnotetext{
* Correspondence: miurashimura@yahoo.co.jp

'Department of Neurology, Juntendo University Urayasu Hospital, 2-1-1

Tomioka, Urayasu, Chiba, Japan

${ }^{3}$ Institute for Environment and Gender Specific Medicine, Juntendo

University School of Medicine, Chiba, Japan

Full list of author information is available at the end of the article
}

is a more effective singlet oxygen scavenger than Lhistidine, although both compounds have been shown to protect against oxidative DNA damage and against liposome oxidation induced experimentally in vitro [12].

Histidine is a scavenger of hydroxyl radicals [13], and may interact chemically with toxic oxygen species through at least two distinct mechanisms: (1) by interfering with the redox reactions involving metal ions that produce the hydroxyl radical, and (2) by direct interactions of the histidine imidazole ring with singlet oxygen [14]. The imidazole ring of L-histidine has been shown to be responsible for the antioxidant activity of several biologically important dipeptides, including carnosine ( $\beta$-alanyl-L-histidine), anserine ( $\beta$-alanyl-3-methyl-L-histidine), and homocarnosine (l-aminobutyryl-L-histidine) [12]. Ala-His-Lys, Pro-His-His, and Tyr-His-Tyr were also reported to have antioxidant properties [15-17].

We hypothesized that histidine-containing tripeptides might also have antioxidant activity. In the present study, we synthesized and determined the antioxidant activities of tripeptides containing histidine and the small amino acids alanine and glycine. 


\section{Methods}

\section{Peptides}

The histidine-containing tripeptides Gly-His-His (GHH), Ala-His-His (AHH), Ala-His-Ala (AHA), Ala-Ala-His (AAH), Ala-Gly-His (AGH), Gly-Ala-His (GAH), AlaHis-Gly (AHG), His-Ala-Gly (HAG), His-His-His $(\mathrm{HHH})$, Gly-His-Ala (GHA), and Gly-Gly-His (GGH) were synthesized by and purchased from Biogate (Gifu, Japan). Carnosine was purchased from Sigma-Aldrich (St. Louis, MO, USA). GAH at $1 \mu \mathrm{g} / \mu \mathrm{l}=3530 \mu \mathrm{M}$.

\section{Cell culture}

PC12 (CRL-1721), SH-SY5Y (CRL-2266) and Jurkat cells (CRL-1990) were purchased from ATCC. PC12, Jurkat, and $\mathrm{SH}-\mathrm{SY} 5 \mathrm{Y}$ cells were grown at $37{ }^{\circ} \mathrm{C}\left(5 \% \mathrm{CO}_{2}\right.$ atmosphere) in RPMI 1640 medium supplemented with 10\% heat-inactivated horse serum, 5\% heat-inactivated fetal bovine serum, $2 \mathrm{mM}$ L-glutamine, $1 \mathrm{mM}$ sodium pyruvate, $100 \mathrm{U} / \mathrm{mL}$ of penicillin, and $100 \mathrm{mg} / \mathrm{mL}$ of streptomycin. Cell culture medium was changed three times per week, and when confluent, cells were split 1:6. For the experiments reported here, subconfluent cells were treated with different concentrations of 100-10,000 $\mu \mathrm{M}$ hydrogen peroxide, $10 \mu \mathrm{M}$ staurosporine, or $500 \mu \mathrm{g} / \mathrm{mL}$ of actinomycin D.

\section{Lactate dehydrogenase assay}

To assess cytotoxicity, lactate dehydrogenase (LDH) activity was measured using LDH cytotoxicity detection kits (Takara, Otsu, Shiga Japan). PC-12 cells were seeded into a 96-well plate at $2 \times 10^{6}$ cells $/ \mathrm{mL}$ with assay medium, for a period of $18 \mathrm{~h}$ at $37{ }^{\circ} \mathrm{C}$ in a $5 \% \mathrm{CO}_{2} \mathrm{hu}$ midified incubator. The culture medium was then removed and replaced with serum-free medium and $1 \%$ bovine serum albumin (BSA) was added. The plates were treated with 100-5000 $\mathrm{MM}$ hydrogen peroxide for 1$24 \mathrm{~h}$. After incubation, the samples were centrifuged for $10 \mathrm{~min}$ at $250 \mathrm{~g}$. One hundred $\mu \mathrm{L} /$ well of supernatant was removed, without disturbing the cell pellet, and transferred into corresponding wells of a new 96-well plate. Solution $\mathrm{C}(100 \mu \mathrm{L}$, the reaction mixture) was added to each well and incubated for $30 \mathrm{~min}$ at room temperature. The 96-well plate was protected from light during this time. The absorbance of the samples was measured at $490 \mathrm{~nm}$ using the ARVO SX 1420 Multilabel Counter (PerkinElmer Wallac Inc., Turku, Finland).

\section{Flow cytometry analysis}

Cells were washed twice with buffer $(140 \mathrm{mM} \mathrm{NaCl}$, $10 \mathrm{mM}$ HEPES, $2.5 \mathrm{mM} \mathrm{CaCI}_{2}, \mathrm{pH}$ 7.4), resuspended in $1 \mathrm{~mL}$ of the same buffer, and incubated on ice for $30 \mathrm{~min}$ with $5 \mu \mathrm{L}$ of propidium iodide $(50 \mu \mathrm{g} / \mathrm{mL}$ $\mathrm{H}_{2} \mathrm{O}$ stock solution) added to each sample. They were then analyzed by flow cytometry (Becton Dickinson, San Jose, CA, USA) [18].

\section{Terminal deoxynucleotidyl transferase dUTP nick end labeling (TUNEL) assay}

The TUNEL assay of PC12 cells was conducted using the Click-iT TUNEL Alexa Fluor 594 Imaging Assay Kit (Molecular Probes ${ }^{\mathrm{Ts}}$, Eugene, OR, USA). DNase I was used to generate strand breaks in the DNA to provide a positive TUNEL reaction control. The number of Alexa Fluor 594-positive cells was counted using BZ-II Analyzer software (Keyence, Japan). Nuclear was stained with 4', 6-diamidino-2phenylindole (DAPI).

\section{Dead cell images}

PC12 cells were incubated for $30 \mathrm{~min}$ at $37{ }^{\circ} \mathrm{C}$ with $4 \mu \mathrm{M}$ of the EthD-1 (LIVE/DEAD viability/cytotoxicity kit reagent (Thermo Fisher Scientific Inc., Waltham, MA, USA). EthD-1 enters cells with damaged membranes and undergoes a 40-fold enhancement of fluorescence upon binding to nucleic acids, thereby producing a bright red fluorescence in dead cells (excitation/emission, $\sim 495 \mathrm{~nm} / 635 \mathrm{~nm}$, respectively). The number of Alexa Fluor 594-positive cells was counted using BZ-II Analyzer software (Keyence).

\section{Cell viability analysis}

Cell growth was assessed using the Cell Counting Kit-8 (CCK-8; Dojindo, Japan) assay. The cells $(2 \times$ $10^{4}$ ) were plated in $100 \mu \mathrm{L}$ of media and added to $100 \mu \mathrm{L}$ of hydrogen peroxide with or without $\mathrm{GAH}$ or carnosine in each well of a 96-well flat-bottomed microtiter plate. Assays were done in triplicate cultures and incubated at $37{ }^{\circ} \mathrm{C}$ in an incubator with $5 \%$ $\mathrm{CO}_{2}$. Ten $\mu \mathrm{L}$ of the CCK 8 solution was added to each well after $24 \mathrm{~h}$ of treatment, and the cells were cultured for another $2 \mathrm{~h}$ at $37{ }^{\circ} \mathrm{C}$. The absorbance was measured using a microplate reader (Nanoquant Plate $^{\mathrm{Tm}}$; Tecan, Männedorf, Switzerland), at $450 \mathrm{~nm}$ with $600 \mathrm{~nm}$ used as the reference wavelength. The cell viability was expressed as a percentage of absorbance in cells with indicated treatments to that of the control cells.

\section{Statistical analysis}

All values are expressed as mean \pm SEM. One-way analysis of variance and post hoc Fisher's protected least significant difference tests were used to determine the significance of differences between the groups. $P$ values $<0.05$ indicated significant difference. 


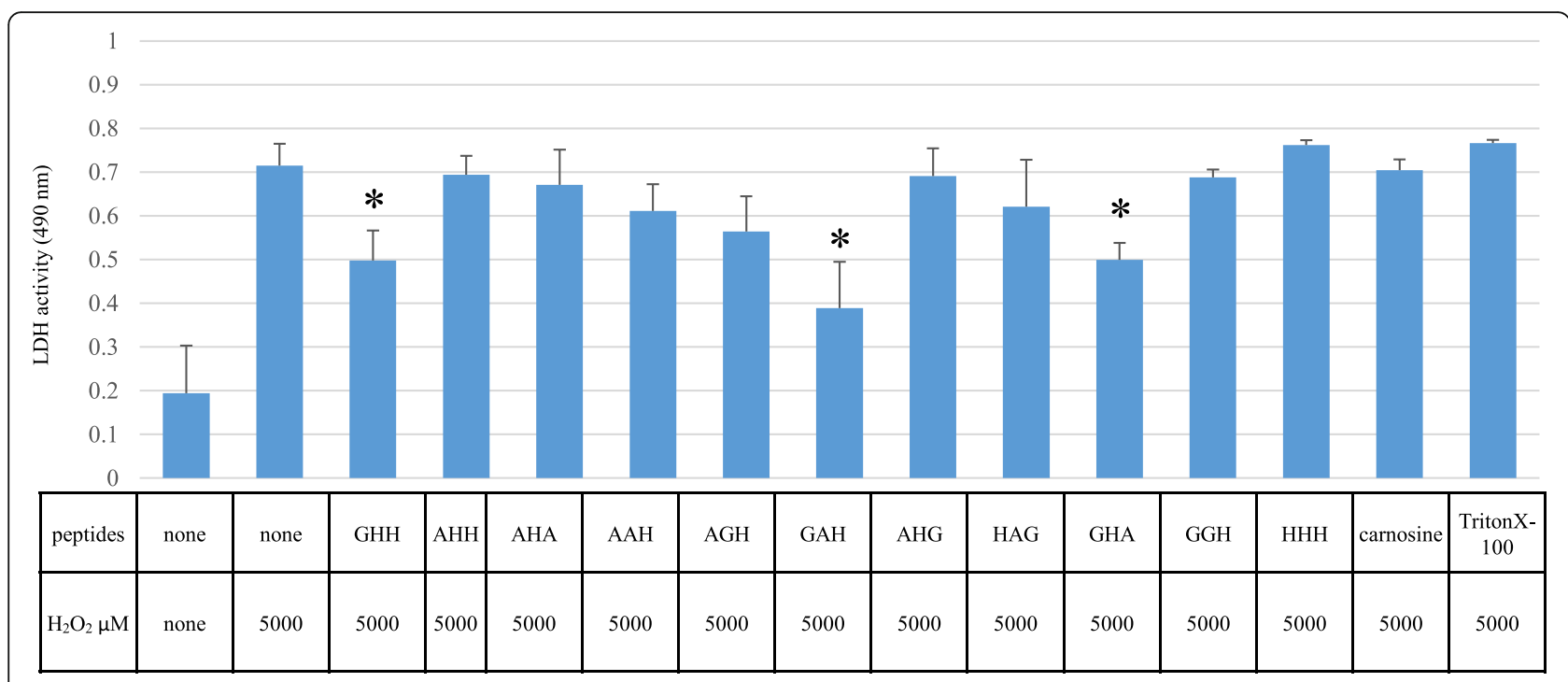

Fig. 1 GAH protects against PC12 cell damage caused by hydrogen peroxide. The effect of histidine-containing tripeptides on hydrogen peroxideinduced cell damage as assessed by measuring lactate dehydrogenase $(\mathrm{LDH})$ release into the medium in PC12 cells in culture. PC12 cells were incubated with $5000 \mu \mathrm{M}$ hydrogen peroxide without or with $1 \mu \mathrm{g} / \mu \mathrm{L}$ of $\mathrm{GHH}, \mathrm{AHH}, \mathrm{AHA}, \mathrm{AAH}, \mathrm{AGH}, \mathrm{GAH}, \mathrm{AHG}, \mathrm{HAG}, \mathrm{HHH}, \mathrm{GHA}, \mathrm{GGH}$, or AH carnosine for $4 \mathrm{~h}$. PC12 cells were also incubated with Triton X100 as a positive control. The quantity of released LDH was estimated in the suspension aliquot from the 96-well plate. Measurements of the means \pm standard deviation (S.D.) of at least four determinations for each sample were obtained by measuring at $490 \mathrm{~nm}$. All of the above additives use the letter designation for the respective amino acid (i.e., $\mathrm{H}=$ histidine). * indicates significant difference $(p<0.001)$ between no peptide and carnosine

\section{Results}

We incubated PC12 cell with $5000 \mu \mathrm{M}$ hydrogen peroxide with $1 \mu \mathrm{g} / \mu \mathrm{L}$ of $\mathrm{GHH}, \mathrm{AHH}, \mathrm{AHA}, \mathrm{AAH}$, AGH, GAH, AHG, HAG, HHH, GHA, GGH, or carnosine for $4 \mathrm{~h}$. GAH, GHH and GHA decreased
LDH leakage compared with either no peptide or with carnosine $(p<0.01)$ (Fig. 1). GAH had the strongest hydrogen peroxide-induced cell deathinhibiting effect of all the tested peptides, and most effectively decreased cell damage in each experiment.

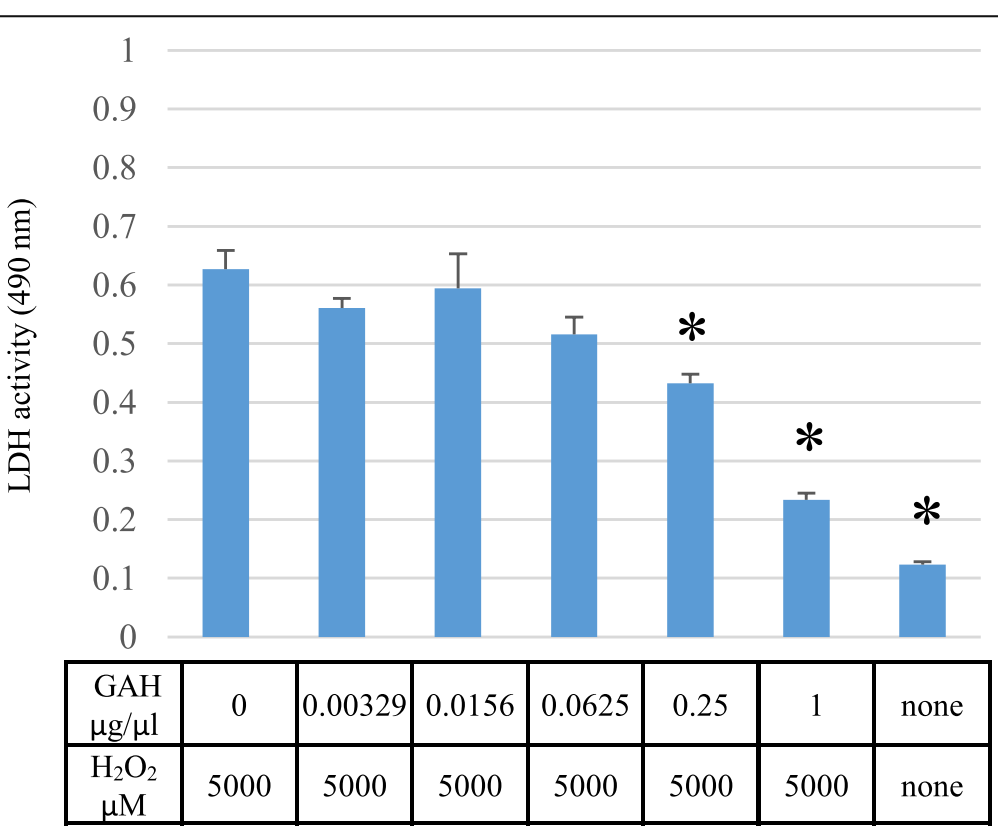

Fig. 2 Cell protective effects activity of GAH are concentration-dependent. PC12 cells were incubated with $5000 \mu \mathrm{M}$ hydrogen peroxide for $4 \mathrm{~h}$ without or with different concentrations of GAH $(0.00329,0.0156,0.0625,0.25$, and $1 \mu \mathrm{g} / \mu \mathrm{L})$. All data are shown as mean \pm SE of three independent experiments. * indicates significant difference $(p<0.01)$ between no peptide. LDH = lactate dehydrogenase 

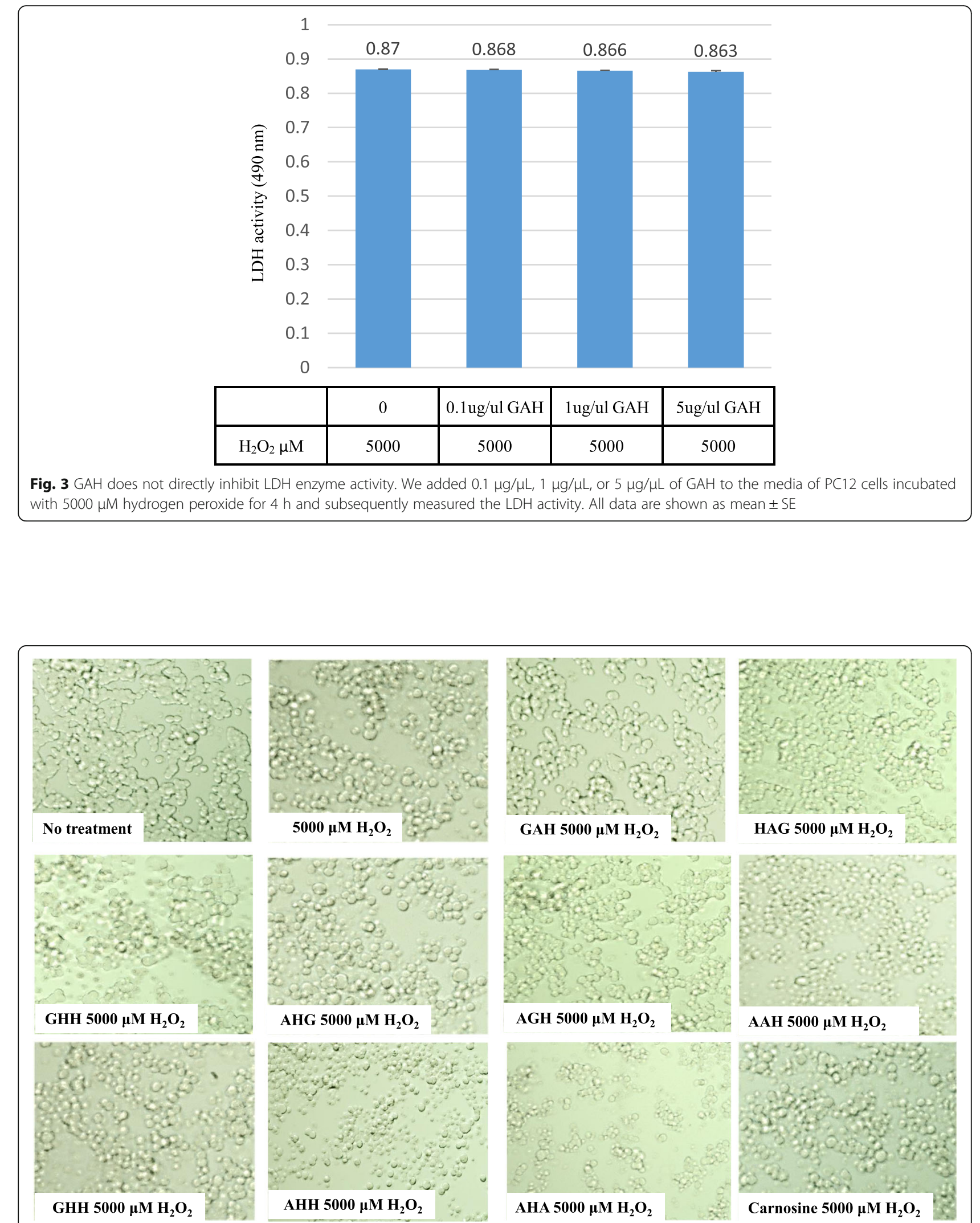

Fig. 4 Micrographs representative of shape changes of PC12 cells. PC12 cells were incubated with $5000 \mu \mathrm{M}$ hydrogen peroxide for $4 \mathrm{~h}$ with or without $1 \mu \mathrm{g} / \mu \mathrm{L}$ of $\mathrm{GHH}, \mathrm{AHH}, \mathrm{AHA}, \mathrm{AAH}, \mathrm{AGH}, \mathrm{GAH}, \mathrm{AHG}, \mathrm{HAG}, \mathrm{HHH}, \mathrm{GHA}, \mathrm{GGH}$, or AH carnosine for $4 \mathrm{~h}$ 
We confirmed GAH cytoprotective activity in at least 20 independent experiments. We then analyzed the cytoprotective functions of $\mathrm{GAH}$, compared to the other tripeptides used in this study.

To determine whether the cell protective activity of GAH was concentration-dependent, we incubated the cells with $5000 \mu \mathrm{M}$ of hydrogen peroxide for $4 \mathrm{~h}$ without or with different concentrations of $\mathrm{GAH}$ $(0.00329,0.0156,0.0625,0.25$, and $1 \mu \mathrm{g} / \mu \mathrm{L})$. GAH at $0.25 \mu \mathrm{g} / \mu \mathrm{L}$ decreased the amount of $\mathrm{LDH}$ release $(p$ $<0.01)$, and $1 \mu \mathrm{g} / \mu \mathrm{L}$ GAH was even more effective in this assay $(p<0.01)$ (Fig. 2). Thus, the highest concentration of GAH tested here had the best cytoprotective activity. We then determined whether GAH directly inhibited LDH enzyme activity. PC12 cells were incubated with $5000 \mu \mathrm{M}$ hydrogen peroxide and culture media was collected and assayed. Different concentrations of GAH were added to the media and the $\mathrm{LDH}$ activity was determined. $\mathrm{GAH}$ at $0.1 \mu \mathrm{g} / \mu \mathrm{L}$, $1 \mu \mathrm{g} / \mu \mathrm{L}$, and $5 \mu \mathrm{g} / \mu \mathrm{L}$ did not inhibit enzyme activity (Fig. 3). These results indicate that GAH did not directly block LDH activity, but most likely prevented its leakage into the media, caused by loss of membrane integrity.

Cell morphology assessments showed that hydrogen peroxide treatment decreased the number of adherent PC12 cells and increased the number of nonadherent cells, resulting in a change from a flat-shaped to a round-shaped cell. The addition of GAH together with hydrogen peroxide increased the number of adherent cells and maintained the flat shape of the cell compared to the effect of hydrogen peroxide alone or after coculture with HAG, GHH, AHG, AGH, AAH, GHH, AHH, AHA, or carnosine (Fig. 4). We next examined the mechanism of cell protection by GAH using the ethidium bromide homodimer 1 from the LIVEDEAD ${ }^{\circ}$ Viability Cytotoxicity Kit (Molecular Probes ${ }^{\mathrm{Tm}}$ ) to stain dead cells. PC12 cells were incubated with ethidium homodimer 1 after treatment with $5000 \mu \mathrm{M}$ hydrogen peroxide for $4 \mathrm{~h}$ in the presence or absence of GAH. The number of dead cells per 100 cells was calculated. GAH and carnosine significantly protected against hydrogen peroxide-induced cell death $(p<0.01)$, GAH more strongly than carnosine $(p<0.01)$ (Fig. 5).

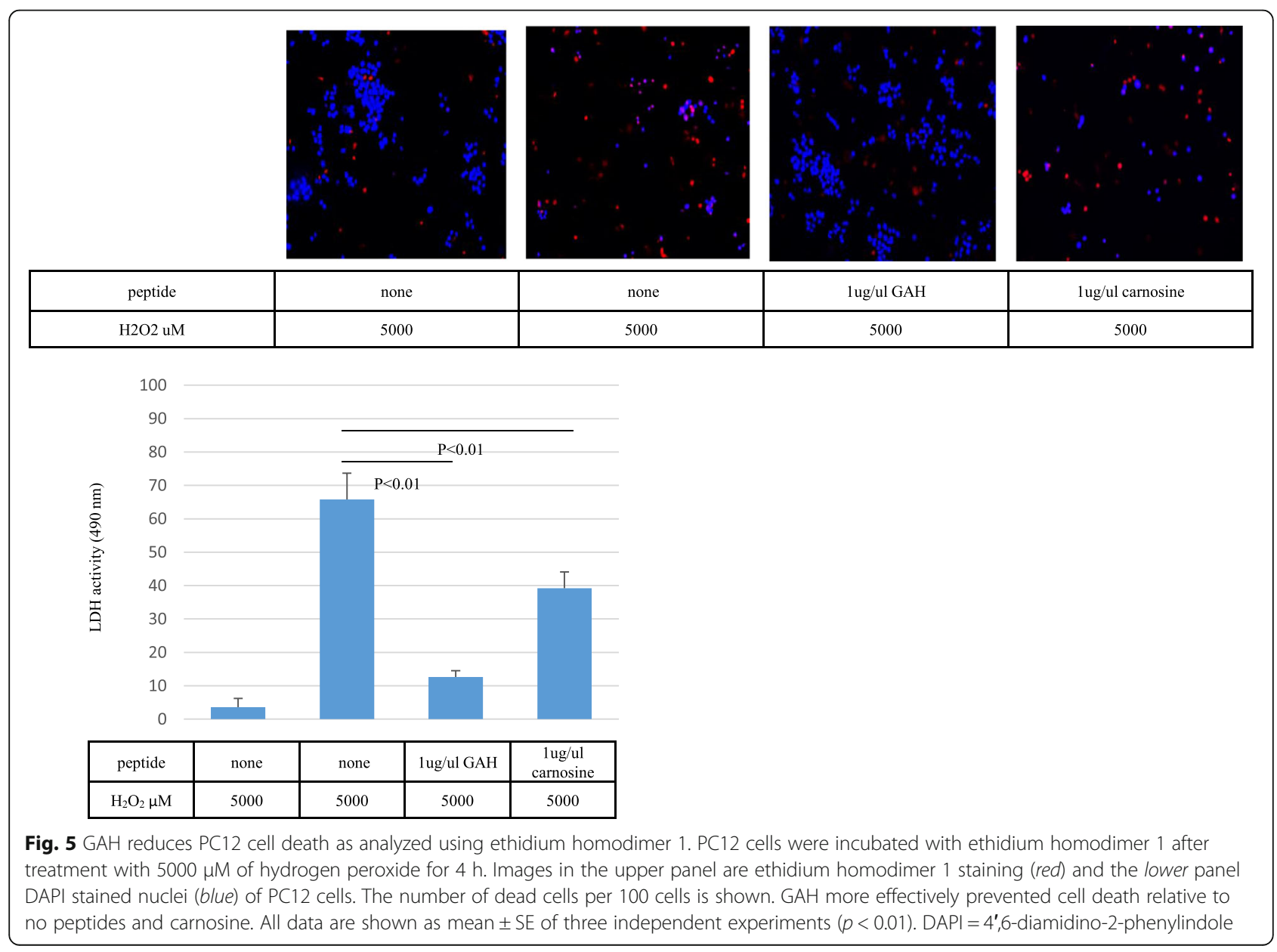


Flow cytometric analyses were performed on the cells after propidium iodide (PI) staining to evaluate the effects of GAH on PC12 cells treated with $500 \mu \mathrm{M}$ of hydrogen peroxide for $4 \mathrm{~h}$. As shown in Fig. 6, the percentage of PI-positive PC12 cells was $28.13 \pm 4.88 \%$ without hydrogen peroxide, and $60.95 \pm 14.82 \%$ with $500 \mu \mathrm{M}$ of hydrogen peroxide, after $4 \mathrm{~h}$. GAH decreased the percentage of PI-positive PC12 cells treated with $500 \mu \mathrm{M}$ hydrogen peroxide by $11.13 \%$ (from $60.95 \pm$ $14.82 \%$ to $49.04 \pm 10.49 \% ; p=0.0219)$. In contrast, carnosine did not significantly affect this parameter (reduced from $60.95 \pm 14.82 \%$ to $59.16 \pm 14.45 \% ; p=$ 0.748). Thus, GAH exerted a cell protective effect superior to that of carnosine.

The percentage of TUNEL-positive PC12 cells was $18.4 \pm 0.87 \%$ without hydrogen peroxide, and $73.1 \pm$ $1.17 \%$ after treatment with $500 \mu \mathrm{M}$ hydrogen peroxide for $24 \mathrm{~h}$. GAH decreased the percentage of TUNELpositive hydrogen peroxide-treated PC12 cells by $60.9 \%$ (from $73.1 \pm 1.17 \%$ to $12.21 \pm 0.078 \% ; p<0.01$ ) (Fig. 7). Carnosine also decreased the percentage of TUNELpositive PC12 cells (by $42 \%$, from $73.1 \pm 1.17 \%$ to $31 \pm$
$3.75 \% ; p<0.01)$. GAH thus prevented apoptosis better than carnosine. Whether the viability of PC12 cells exposed to $100 \mu \mathrm{M}$ hydrogen peroxide was protected by GAH was investigated using the CCK- 8 assay. The results showed that cell viability (as measured at OD $450 \mathrm{~nm})$ was significantly increased in the GAH $(0.625$ $\pm 0.023)$ - and carnosine $(0.711 \pm 0.026)$-treated groups relative to controls $(0.144 \pm 0.012, \mathrm{p}<0.01)$ (Fig. 8). Thus, in this assay, there was no difference between $\mathrm{GAH}$ and carnosine.

We also examined the protective effects of GAH against actinomycin $\mathrm{D}$ and staurosporine-induced apoptotic cell death of PC12 cells [19, 20]. Cells were incubated with $500 \mu \mathrm{g} / \mathrm{mL}$ of actinomycin D or $10 \mu \mathrm{M}$ of staurosporine for $12 \mathrm{~h}$, and viability again measured by the LDH leakage assay. GAH did prevent cell death induced by actinomycin $\mathrm{D}(p<0.001)$ and staurosporine $(p<0.001))$ similar to its effects on hydrogen peroxide toxicity (Fig. 9).

We also examined the effect of GAH on Jurkat cells (human lymphocyte cell type) and SH-SY5Y cells (human neuroblastoma cells) in culture. Jurkat cells were

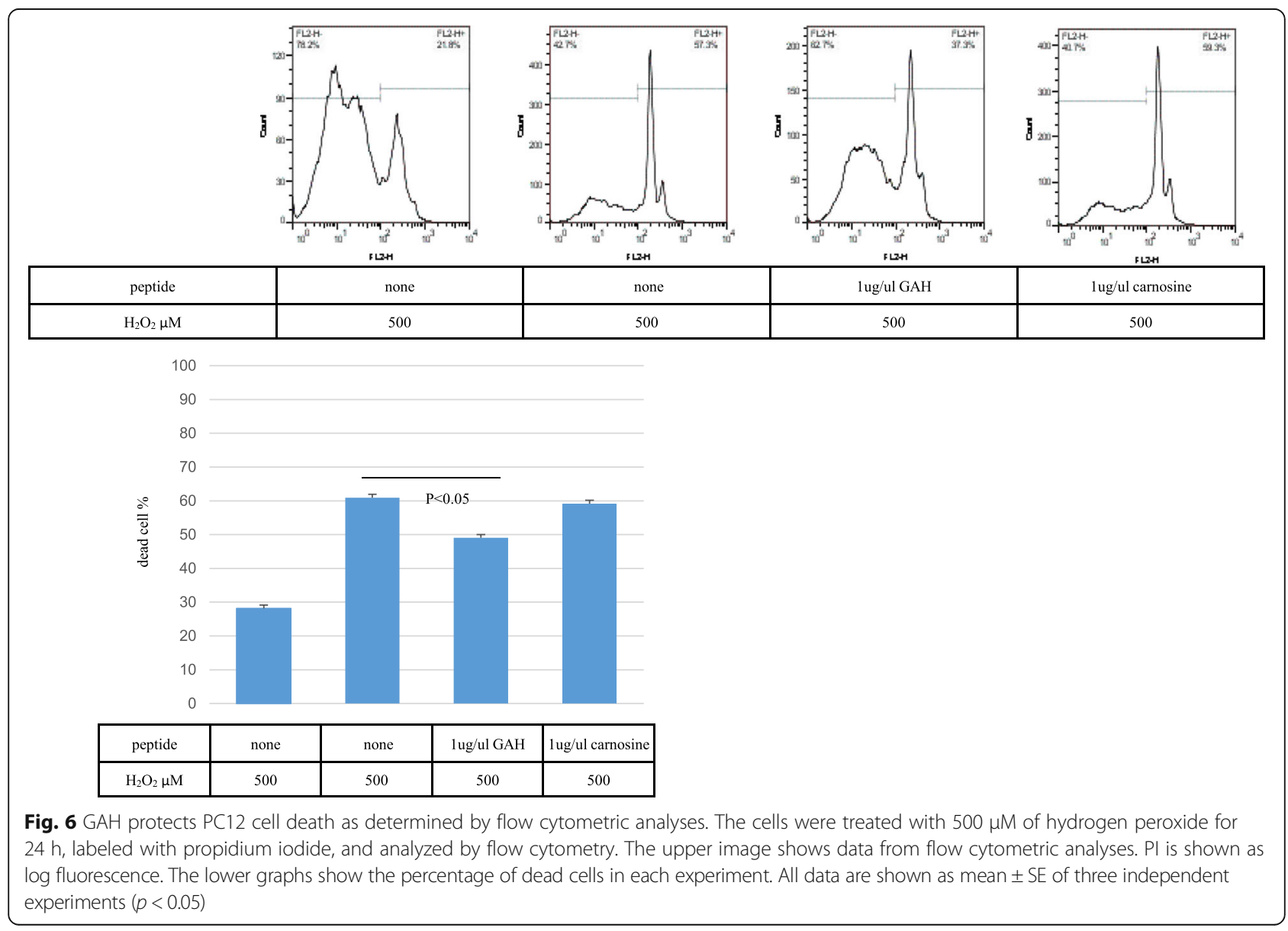




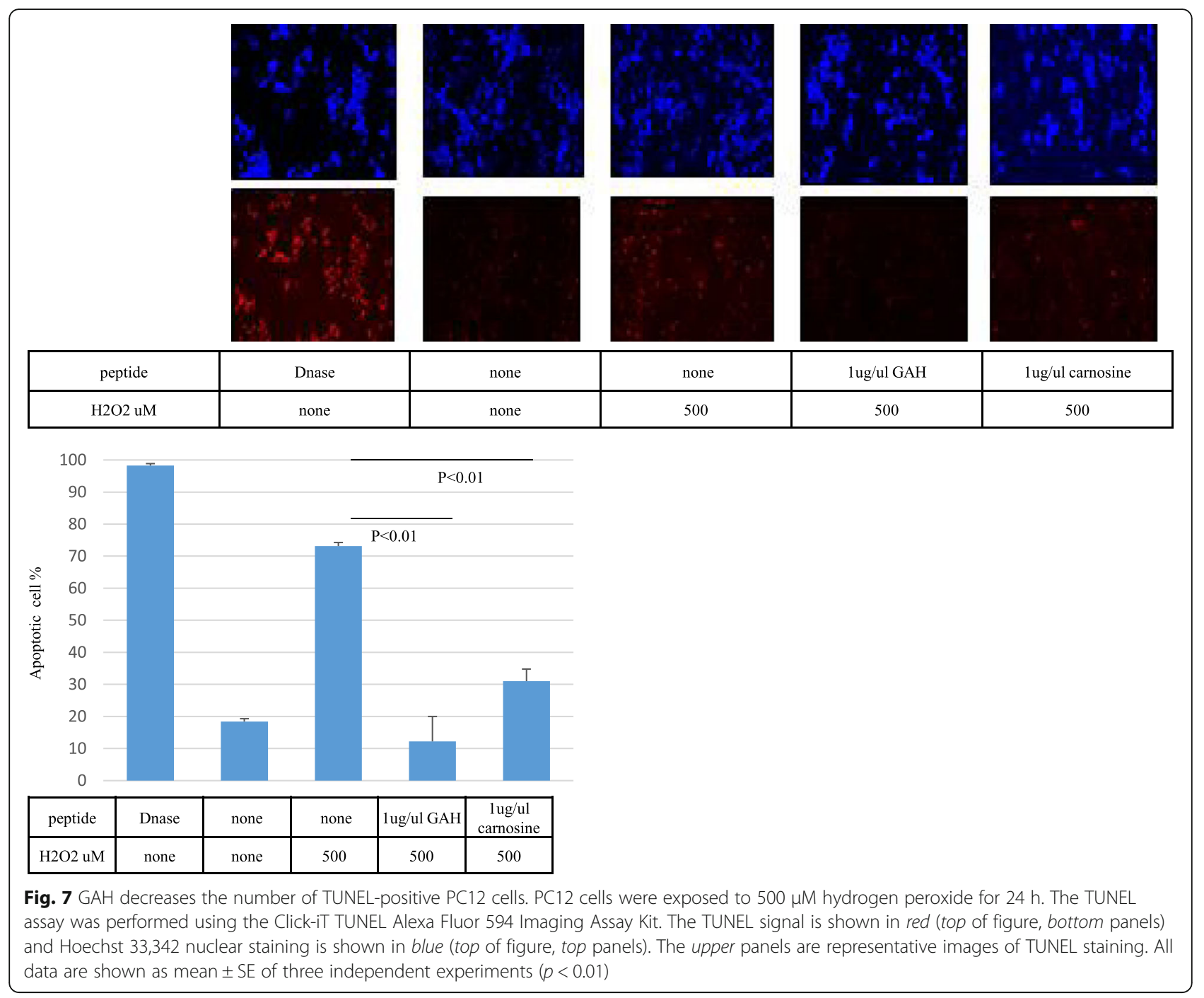

incubated with $10,000 \mu \mathrm{M}$ of hydrogen peroxide for $4 \mathrm{~h}$. $\mathrm{GAH}$ at $1 \mu \mathrm{g} / \mu \mathrm{L}$ decreased the amount of LDH release from Jurkat cells $(p<0.001)$ (Fig. 10a). We also incubated SH-SY5Y cells with $1000 \mu \mathrm{M}$ of hydrogen peroxide for $24 \mathrm{~h}$ in the presence or absence of GAH. At $1 \mu \mathrm{g} / \mu \mathrm{L}$, $\mathrm{GAH}$ also decreased the amount of LDH released from SH-SY5Y cells $(p=0.0039)$ (Fig. 10b). These findings indicate that GAH prevents Jurkat and SH-SY5Y cell membrane damage caused by hydrogen peroxide.

\section{Discussion}

We screened newly synthesized histidine-containing tripeptides for their radical scavenging activity. GHH, AHH, AHA, AAH, AGH, GAH, AHG, HAG, HHH, GHA, and GGH were screened for their ability to decrease LDH leakage from PC12 cells treated with hydrogen peroxide. Of these peptides, GAH at $1 \mu \mathrm{g} / \mu \mathrm{L}$ had the strongest protective effect against cell damage as assessed by LDH leakage, by ethidium bromide staining, cell morphology, TUNEL assays, CCK- 8 assays, and PI assays. GAH also protected Jurkat cells and SH-SY5Y cells; it may therefore have a protective effect against many different types of cells. GAH was not effective for SH-SY5Y cells compared to PC12 cells suggesting that effectiveness of GAH might depends on cell type.

Several histidine-containing dipeptides or tripeptides with antioxidant activity have been identified. Hartman et al. [21] have shown that carnosine is an efficient singlet-oxygen scavenger, quenching singlet oxygen more effectively than histidine. They also reported that carnosine, anserine, and histidine protect phages against gamma-irradiation, which gives rise to oxidative DNA damage. Tsuge et al. reported the isolation of a potent antioxidative peptide, Ala-His-Lys, from an egg white albumin hydrolysate [15]. Chen et al. reported that Pro- 


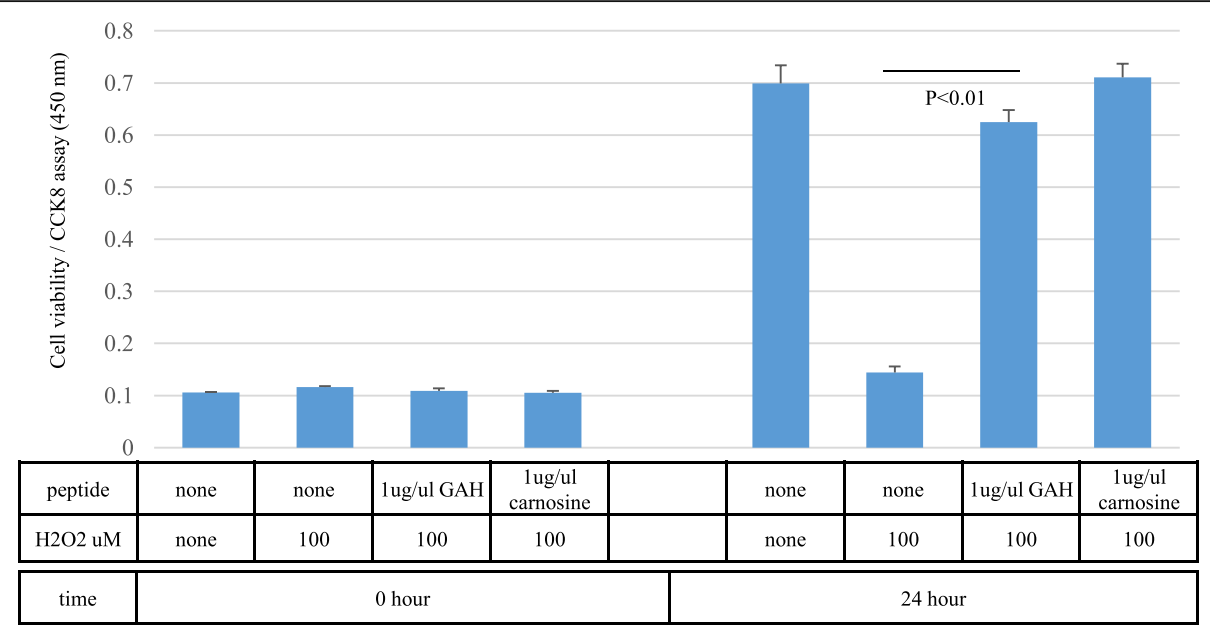

Fig. 8 GAH protects PC12 cells as measured by the CCK-8 assay. PC12 cells were exposed to $100 \mu \mathrm{M}$ hydrogen peroxide. Cell viability was measured using the CCK-8 assay at the start and after $24 \mathrm{~h}$ incubation. All data are shown as mean \pm SE of three independent experiments $(p<0.01)$

His-His was the most active antioxidant among the 28 synthetic peptides that were structurally related to LeuLeu-Pro-His-His [16]. Saito et al. reported that Tyr-His-Tyr had a strong synergistic effect with phenolic antioxidants [17]. As reported here, GAH attenuated cell damage by hydrogen peroxide, suggesting that it might be an efficient singlet oxygen scavenger, similar to carnosine, Pro-His-His, and Tyr-His-Tyr.

GAH protected cells not only against hydrogen peroxide damage, but also prevented apoptosis induced by staurosporine and actinomycin D. Staurosporine is a broad-spectrum inhibitor of protein kinases, and has been widely used for the induction of apoptosis in diverse cellular models [22, 23]. Staurosporine preferentially activates the mitochondrial apoptotic pathway, relying on caspase activation to cause cell death. Actinomycin D, on the other hand, is a widely-used intercalating transcription inhibitor. [24]. Protection by GAH against hydrogen peroxide, staurosporine, and actinomycin D suggests that it might not only be a radical scavenger but could also protect by other mechanisms. The protective effects of carnosine include actions on glycolytic enzymes, metabolic regulatory activities, redox biology, protein glycation, glyoxalase activity, apoptosis, gene expression, and cancer cell metastasis [25].

In this study, we did not address the mechanism of how GAH attenuated cell death. Further studies will be needed to clarify the mechanism of GAH cytoprotection.

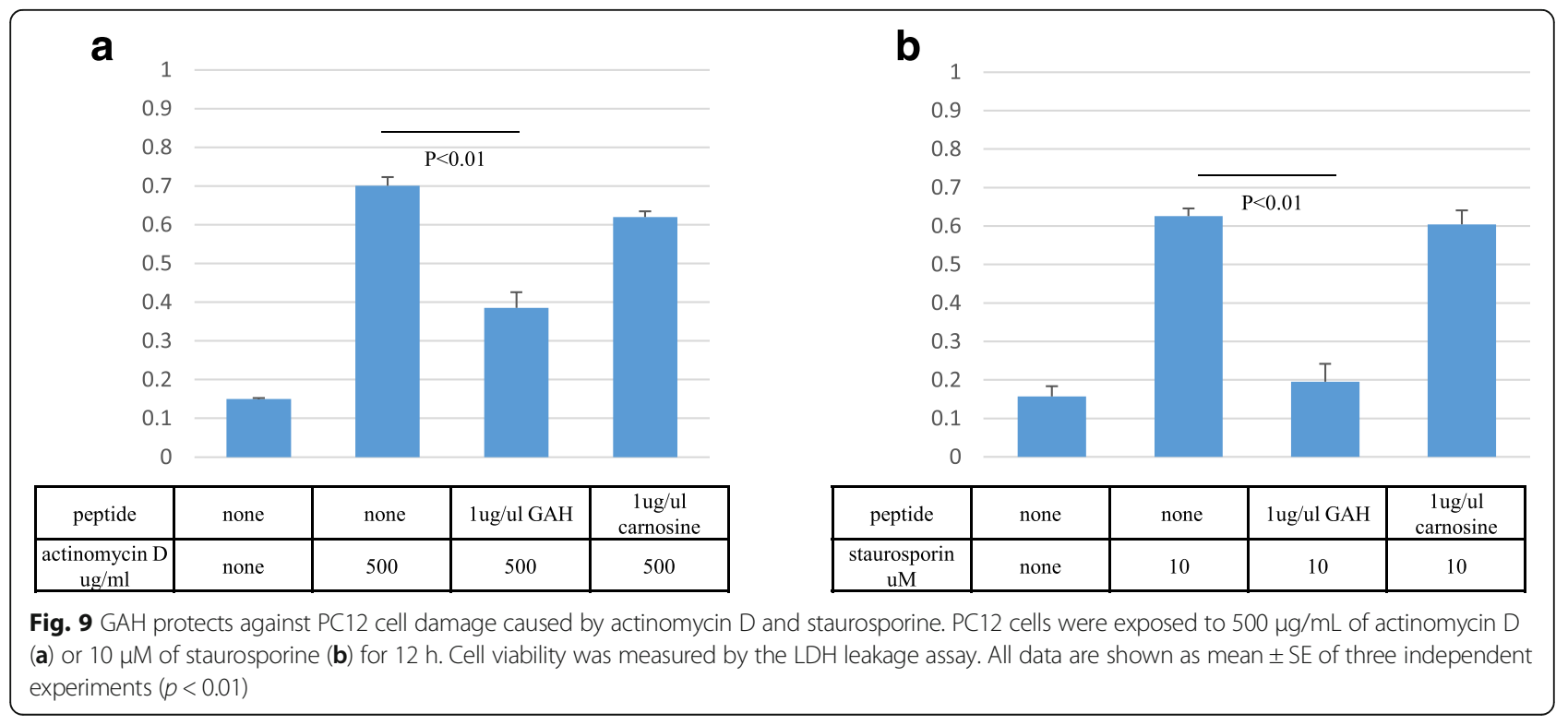



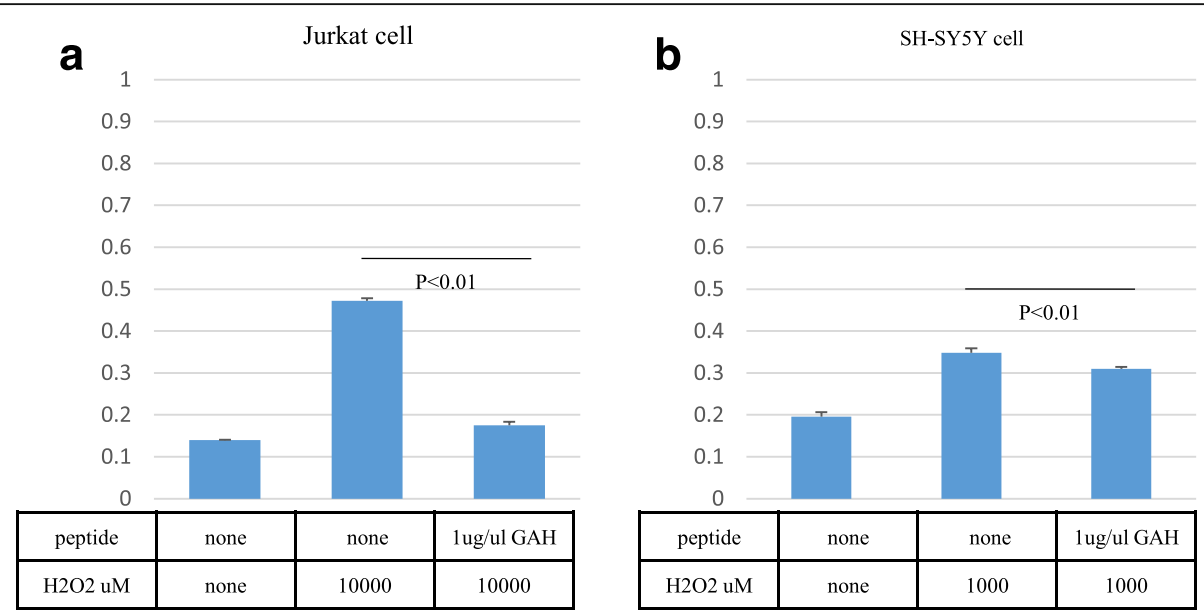

Fig. $10 \mathrm{GAH}$ protects against Jurkat and SH-SY5Y cell damage caused by hydrogen peroxide. Jurkat cells were exposed to 10,000 $\mu \mathrm{M}$ hydrogen peroxide for $4 \mathrm{~h}$ (a). SH-SY5Y cells were exposed to $1000 \mu \mathrm{M}$ hydrogen peroxide for $24 \mathrm{~h}$ (b). Cell viability was measured by the LDH leakage assay. All data are shown as mean \pm SE of three independent experiments $(p<0.01)$

\section{Conclusions}

The present studies showed that GAH has protective effect against cell damage determined by LDH leakage, by ethidium bromide staining, cell morphology, TUNEL assays, CCK-8 assays, and PI assays. GAH also protected Jurkat cells and SH-SY5Y cells. GAH might has a potential for cytoprotective agents.

\section{Acknowledgements}

We acknowledge R Ishikawa for performing experiments.

\section{Funding}

This study was partly supported by a High Technology Research Center grant and a Grant-in-Aid for exploratory research from the Ministry of Education, Culture, Sports, Science and Technology in Japan and by a Grant-in-Aid for Scientific Research from the Japan Society for the Promotion of Science (21,700,395, H. Shimura;) and from the Takeda Science Foundation (H. Shimura). This study was supported (in part) by a Grant-in-Aid (S1311011) from the Foundation of Strategic Research, Projects in Private Universities from the Ministry of Education, Culture, Sports, Science, and Technology, Japan. The funders had no role in study design, data collection and analysis, decision to publish, or preparation of the manuscript.

\section{Availability of data and materials}

The datasets generated and/or analysed during the current study are available from the corresponding author on reasonable request.

\section{Authors' contributions}

HS designed and performed the experiments, participated in the interpretation of data, and wrote manuscript. RT, YS, KY performed the biological experiments. $\mathrm{NH}$, TU designed the experiments, interpreted the data, and wrote the manuscript. All the authors read and approved the final manuscript.

\section{Ethics approval and consent to participate}

Not applicable

\section{Consent for publication}

Not applicable

\section{Competing interests}

The authors declare that they have no competing interests.

\section{Publisher's Note}

Springer Nature remains neutral with regard to jurisdictional claims in published maps and institutional affiliations.

\section{Author details}

'Department of Neurology, Juntendo University Urayasu Hospital, 2-1-1 Tomioka, Urayasu, Chiba, Japan. ${ }^{2}$ Department of Neurology, Juntendo University School of Medicine, Tokyo, Japan. ${ }^{3}$ Institute for Environment and Gender Specific Medicine, Juntendo University School of Medicine, Chiba, Japan.

Received: 1 March 2017 Accepted: 9 November 2017

Published online: 22 November 2017

\section{References}

1. Padhi A, Sengupta M, Sengupta S, Roehm KH, Sonawane A. Antimicrobial peptides and proteins in mycobacterial therapy: current status and future prospects. Tuberculosis (Edinb). 2014;94:363-73.

2. Buchwald H, Dorman RB, Rasmus NF, Michalek VN, Landvik NM, Ikramuddin S. Effects on GLP-1, PYY, and leptin by direct stimulation of terminal ileum and cecum in humans: implications for ileal transposition. Surg Obes Relat Dis. 2014;10:780-6.

3. Robinson SD, Safavi-Hemami H, Mclntosh LD, Purcell AW, Norton RS, Papenfuss AT. Diversity of conotoxin gene superfamilies in the venomous snail, Conus Victoriae. PLoS One. Public Libr Sci. 2014;9:e87648.

4. Fosgerau K, Hoffmann T. Peptide therapeutics: current status and future directions. Drug Discov Today. 2014;20:122-8.

5. Yagasaki M, Hashimoto S. Synthesis and application of dipeptides; current status and perspectives. Appl Microbiol Biotechnol. 2008:81:13-22.

6. Santos S, Torcato I, Castanho MARB. Biomedical applications of dipeptides and tripeptides. Biopolymers. 2012;98:288-93.

7. Chakraborty S, Tai D-F, Lin Y-C, Chiou T-W. Antitumor and antimicrobial activity of some cyclic tetrapeptides and tripeptides derived from marine bacteria. Mar Drugs. 2015;13:3029-45.

8. Faden AI, Knoblach SM, Movsesyan VA, Lea PM, Cernak I. Novel neuroprotective tripeptides and dipeptides. Ann N Y Acad Sci. 2005; 1053:472-81.

9. Turpeinen $A M$, Järvenpää $S$, Kautiainen $H$, Korpela $R$, Vapaatalo $H$. Antihypertensive effects of bioactive tripeptides-a random effects metaanalysis. Ann Med. 2013:45:51-6.

10. Baye E, Ukropcova B, Ukropec J, Hipkiss A, Aldini G, de Courten B. Physiological and therapeutic effects of carnosine on cardiometabolic risk and disease. Amino Acids. 2016;48:1131-49.

11. Chan KM, Decker EA. Endogenous skeletal muscle antioxidants. Crit Rev Food Sci Nutr. 1994;34:403-26. 
12. Kohen R, Yamamoto Y, Cundy KC, Ames BN. Antioxidant activity of carnosine, homocarnosine, and anserine present in muscle and brain. Proc Natl Acad Sc U S A. 1988:85:3175-9.

13. Wade AM, Tucker HN. Antioxidant characteristics of L-histidine 11The work described in this manuscript was partially sponsored and funded by Cytos pharmaceuticals. LLC J Nutr Biochem Elsevier. 1998;9:308-15.

14. Kussman M, Stover PJ. Nutrigenomics and Proteomics in Health and Disease: Food Factors and Gene Interactions. John Wiley \& Sons; 2009

15. Tsuge N, Eikwa Y, Nomura Y, Yamamoto M, Sugisawa K. Antioxidative activity of peptides prepared by enzymatic hydrolysis of egg-white albumin. J Agric Chem Soc Japan. 1991;65:1635-41.

16. Chen H-M, Muramoto K, Yamauchi F, Nokihara K. Antioxidant activity of designed peptides based on the Antioxidative peptide isolated from digests of a soybean protein. J Agric Food Chem American Chemical Society. 1996:44:2619-23.

17. Saito K, Jin D-H, Ogawa T, Muramoto K, Hatakeyama E, Yasuhara T, et al. Antioxidative properties of tripeptide libraries prepared by the combinatorial chemistry. J Agric Food Chem. 2003;51:3668-74.

18. Boccellino M. Styrene-7,8-oxide activates a complex apoptotic response in neuronal PC12 cell line. Carcinogenesis. 2003;24:535-40.

19. Lindenboim L, Haviv R, Stein R. Inhibition of drug-induced apoptosis by survival factors in PC12 cells. J Neurochem 1995:64:1054-63.

20. Ivins KJ, Ivins JK, Sharp JP, Cotman CW. Multiple pathways of apoptosis in PC12 cells: CrmA INHIBITS APOPTOSIS INDUCED BY -AMYLOID. J Biol Chem American Society for Biochemistry and Molecular Biology. 1999;274:2107-12.

21. Dahl TA, Midden WR, Hartman PE. SOME PREVALENT BIOMOLECULES AS DEFENSES AGAINST SINGLET OXYGEN DAMAGE. Photochem Photobiol Blackwell Publishing Ltd. 1988;47:357-62.

22. Tamaoki T, Nomoto H, Takahashi I, Kato Y, Morimoto M, Tomita F. Staurosporine, a potent inhibitor of phospholipidCa++dependent protein kinase. Biochem Biophys Res Commun Academic Press. 1986;135:397-402.

23. Rüegg UT, Gillian B. Staurosporine, K-252 and UCN-01: potent but nonspecific inhibitors of protein kinases. Trends Pharmacol Sci Elsevier Current Trends. 1989;10:218-20.

24. Perry RP, Kelley DE. Inhibition of RNA synthesis by actinomycin D: characteristic dose-response of different RNA species. J Cell Physiol. 1970;76:127-39.

25. Hipkiss AR, Gaunitz F. Inhibition of tumour cell growth by carnosine: some possible mechanisms. Amino Acids. 2014;46:327-37.

\section{Submit your next manuscript to BioMed Central and we will help you at every step:}

- We accept pre-submission inquiries

- Our selector tool helps you to find the most relevant journal

- We provide round the clock customer support

- Convenient online submission

- Thorough peer review

- Inclusion in PubMed and all major indexing services

- Maximum visibility for your research

Submit your manuscript at www.biomedcentral.com/submit 